\title{
Poetic Wisdom, Mind and Senses, Media. How to Deal With Phenomenon of Crisis of Humanities?
}

\author{
Bartłomiej Knosala \\ Silesian University of Technology, Gliwice, Poland
}

\begin{abstract}
The today culture seems to be torn by two contradicted phenomena. First is connected with crisis of humanities, second with stepping of arts into the new spheres. Based on the thought of Marshall McLuhan, Giambatistta Vico and Rudolf Arnheim we will display that this contradiction is only apparent. After Marshall McLuhan we acknowledge the power of media to change the patterns of cognition and after Rudolf Arnheim we acknowledge the intimate relation between senses and mind. On such foundation we will see that crisis of humanities is connected with incorrect understanding relation between mind and senses. As Rudolf Arnheim remarks strict division between senses and mind favors downgrading social role of art and humanities - such division refuses art and humanities right to take a part in cognition. But in the age of electronic/digital culture, which is recovering the simultaneous of the verbi-voco-visual communication, new proportion between our senses is appearing. It must entail new approach to art and humanities.
\end{abstract}

Keywords: crisis of humanities, mind and senses, Marshall McLuhan, Giambatistta Vico, poetic wisdom, Media Ecology, Rudolf Arnheim

\section{Introduction}

If we want to understand the modern culture, culture of second decade of twenty first century, we have to deal with two issues, issues that only seemingly are contradicted. First issue is connected with decreasing of interest in art and humanities in modern culture. Liberal education is accused of lack of usefulness. Peter Drucker in "Post-Capitalist Society" remarked that for generations who took their higher education after Second World War liberal education cannot provide understanding of the world nor manage it (Drucker, 1999, p. 173). In all civilized world young people are persuaded that road to personal success is going through the STEM (Science, Technology, Engineering and Mathematics).

Second issue is connected with the central place of esthetical experience in the fields that previously were not associated with art or humanities. There are new phenomena in our culture in which art and humanities are taking important places. In education is strong current to including art to process of learning. The best example is Sir Ken Robinson and his conviction that remedies for problem of incompatibility of the education system with the needs of the labor market is connected with lack of creative approaches to learning. Robinson suggests that proper method of awakening creativity is through aesthetic experience. Besides education arts and humanities appropriate science and technologies. Roger Malina, editor of Leonardo Journal, remarks that today we find artists working in nanoscience laboratories, space exploration centers, high energy physics accelerator,

Bartłomiej Knosala, Ph.D., Associate Professor, Silesian University of Technology. 
supercomputing centers, and genetic engineering labs (Malina, 2014, p. 5). We are also witnesses of developing FabLabs, places which are making commitment to unite artist and engineer. Neil Gershenfeld creator of FabLabs is convinced that thanks to personal fabrication the new physical notion of literacy is making. For Gershenfeld this new physical notion of literacy means mastery of digital forms of expression (Gershenfeld, 2014, p. 8). New ideas about the role of art are shaping approach to technology of great corporations. The best example is Apple and famous Steve Jobs quotation that "technology alone is not enough. That is technology married with liberal arts, married with the humanities that yield us the result that makes our hearts sing" ${ }^{1}$. The key question, which we have to ask to understand the global culture of twenty first century is how to reconcile these two seemingly contradicted issues.

\section{Assumptions-Technological Determinism, Media Ecology, Mind and Senses}

The basic assumption in this paper is connected with technological determinism. We recognized that social role of art and humanities largely depend on technological development. After Marshall McLuhan and whole tradition of Media Ecology we acknowledge that new modes of communications are changing human perception, forms of organizing knowledge and modes of education. But in public discourse this interdependence between media and forms of knowledge are predominantly not taking under consideration. Our Western culture still considers that ultimate medium for humanities and poetry is phonetic alphabet and moveable type. The phenomena of crisis of humanities are largely connected with this conviction. In this paper we will try to present that crucial categories, which we have used to understand the role of humanities and art in society, are byproducts of modes of communication.

There is direct relationship between convictions concerning roles of literature, poetry and art in society and certain philosophical ideas. As Rudolf Arnheim remarks strict division between senses and mind favors downgrading social role of art and humanities - such division refuses art and humanities right to take a part in cognition. But in the age of electronic/digital culture, which is recovering the simultaneous of the verbi-voco-visual communication, new proportion between our senses is appearing. It must entail new approach to art and humanities. This new approach requires to overcome outmoded categories. Trying to understand the phenomena of role of art and science in society we are facing the effect, which was named by McLuhan rear-view mirror effect. According to McLuhan:

When faced with a totally new situation, we tend always to attach ourselves to the objects, to the flavor of the most recent past. We look at the present through a rear-view mirror. We march backwards into the future. (McLuhan, 2001, p. 75)

According to McLuhan the concept of modern society with strictly divided spheres of science, art and technology is outmoded. From his doctoral thesis "The Place of Thomas Nashe in the Learning of His Time" we can learn how medieval and renaissance authors were important for McLuhan. Some of those authors ignored the boundaries between art, science, magic and history. McLuhan called them grammarians and tried to regain their approach. Many of modern phenomena verify his basic convictions that electronic/digital culture disregards borders of arts, science and technology. Moreover according to McLuhan the feature, which distinguishes our times is the central role of aesthetic experience. It means that to understand the role of art and humanities in modern culture we have to rethink some general categories. In this context we postulate to regain

${ }^{1}$ See from http://www.newyorker.com/news/news-desk/steve-jobs-technology-alone-is-not-enough. 
the notion of poetic wisdom as characteristic feature of our times. Such restoration of the notion of poetic wisdom must be done in two steps. First we have to outline the relation between mind and senses in the process of cognition. From that relation depends our understanding of role of art in society. Here we will follow Rudolf Arnheim's Visual Thinking. Second we will try to show how technological devices are changing the modes of perception. Assuming that changes of modes of perception are at the same time passages from one historical period to another we will try to show that suitable concept for our times is the notion of poetic wisdom.

\section{Poetic Wisdom}

Poetic wisdom is the notion introduced by Italian philosopher Giambattista Vico (1668-1744) in his main work New Science. Vico found out that move of the history is caused by two distinct features of human nature: the ages of gods and heroes result from memory and creative acts of "imagination" (fantasia), while the age of men stems from the faculty of "reflection". From this division Vico derived two kinds of wisdom- "poetic" and "philosophical"- corresponding to the dual nature of human beings (sense and intellect), represented in the creations of theological poets and philosophers.

Nations must be "poetic in their beginnings" says Vico in his New Science. All valuable knowledge for them was manifested primarily in fable, myth and the structure of early languages. Metaphysics of notions in the stage of gods and heroes is "not rational and abstract like that of learned men now, but felt and imagined (by men) without power of ratiocination". This metaphysics was their poetry. In the ages of gods and heroes everything was poetry-Vico in his work describes "poetic morals", "poetic cosmography", "poetic astronomy", "poetic chronology", "poetic geography", etc.

Basic faculty of cognition for nations in the ages of gods and heroes were senses. The run of history was going from theological poets who based their knowledge on the senses to philosophers who based their knowledge on the reason. Vico remarks that transition from knowledge based on senses to knowledge based on reason was caused by division senses from mind. How it happened? Vico points to two intellectual devices: ability to count and phonetic alphabet. These were the factors of changes in perception but also the factors of social changes.

\section{Revival of Poetic Wisdom in the Age of Electronic/Digital Culture}

Marshall McLuhan was convinced that philosophy of Vico can provide the frame to understand the modern changes in culture and society. In 1951 McLuhan wrote letter to Harold Innis, Canadian pioneer of theory of communication. In that letter McLuhan observes that,

...when the chief pedagogical thesis of the symbolists poets, which posits that the education of the mind consists in retracing the labyrinthine paths that join the intellect to the senses, is refracted through Vico, for whom it had shaped the discipline of historical philology as well as the actual history of culture, it becomes the basis of modern historiography, archeology, psychology and artistic procedures alike. (Pietropaolo, 1995, p. 55)

In letter to Jacques Maritain McLuhan wrote that Vico in his Scienzia Nouva "asserts the principle of the sensory and perceptual change resulting from new technologies throughout human history” (McLuhan, 1999, p. 70). These two remarks about Vico's philosophy are very core of McLuhan's own thought. From first remark we learn that human cognition is connected with "retracing the labyrinthine paths that join the intellect to the senses". This thesis is equal with the acceptation of existence the intimate relation between senses and mind. The difficulty of this thesis is lying in our cultural acceptance for ancient philosophical tradition, which starts with 
philosophy of Parmenides of Elea and finds its ultimate expression in the great philosophical systems of Plato and Aristotle. Foundations of this tradition are connected with emphasizing the autonomy thinking from the senses and with downgrading of arts in social life. In modern psychology one of the most significant effort of severance with this tradition we can find in Rudolf Arnheim Visual Thinking.

\section{Rudolf Arnheim's Visual Thinking-Art and Thinking Through the Senses}

According to Arnheim's researches in the field of psychology of perception there is intimate relation between senses and mind. Relation — worth of noticed — was ignored in Western culture. Arnheim writes: "only because perception gathers types of thinking, that is, concepts, can perceptual material be used for thought: and inversely, that unless the stuff of the senses remains present the mind has nothing to think with" (Arnheim, 1969, p. v). In his opinion isolation and neglect of the arts in society and education have them source in a split between senses and thought. Such split effects in separation arts from other domains of human life. Arnheim writes:

I could not go along with the view that the arts are to be kept locked up in a sacred precinct, privileged with their own exclusive purposes, laws, procedures. Rather I am convinced that art cannot exist anywhere unless it is property of everything. I also must expect many an experimentalist to feel uncomfortable with the idea that productive thinking ignores the property lines between the aesthetic and the scientific. (Arnheim, 1969, p. v)

According to Arnheim art is an instrument for reasoning and human beings explore and comprehend by acting and handling rather than by mere contemplation, which is after all a rare state (Arnheim, 1969, p. vii). But the basic beliefs of our modern culture are connected with prejudicial, which orders to divide perception from thinking. Arheim writes:

Our entire education system continues to be based on the words and numbers. In kindergarten, to be sure, our youngsters learn by seeing and handling handsome shapes, and invent their own shapes on paper or in clay by thinking through perceiving. But with the first grade of elementary school the senses begin to lose educational status. More and more the arts are considered as a training in agreeable skills, as entertainment and mental release. As the ruling disciplines stress more rigorously the study of words and numbers, their kinship with arts is increasingly obscured, and arts are reduced to desirable supplement; (...) (Arnheim, 1969, p. vii)

According to Arnheim the basic failure of our Western culture relies on isolation of art from other human activities. We must recognize, claims Arnheim, that art is property of every think what we perceive - creative thinking disregards the borders between esthetical and scientific aspects of our reality. Arnheim postulates to recognize the perception as the mode of thinking - he believes that art is powerful tool of amplifying capability of perception and thanks to this art can also amplify creative thinking (Arnheim, 2011, p. 11).

\section{Media and Perception}

From the Arnheim researches emerges one question, which was not asked by author of Visual Thinking. What were material causes of ignoring that intimate relation between mind and senses? According to McLuhan the answer can be connected with the fact that "our sensory order is violatable by technologies" . In the letter to Jacques Maritain McLuhan remarked that Giamabattista Vico's Scienca Nouva "asserts the principle of the sensory and perceptual change resulting from new technologies throughout human history" (McLuhan, 1999, p. 70). In Vico's New Science separation senses form the mind occurs because of the "art of writing" and use of

2 See Phrase from the letter of Marshall McLuhan to Frank Kermode from http://thisrecording.com/today/2011/10/27/in-which-we-know-nothing-of-his-work.html. 
numbers. In the same time these in fact technological devices are factors of the passage from the period of poetical wisdom to the age of reflection. Vico writes:

But the nature of our civilized minds is so detached from the senses, even in the vulgar, by abstractions corresponding to all the abstract terms our languages abound in, and so refined by the art of writing, and as it were spiritualized by the use of numbers, because even the vulgar know how to count and reckon, that it is naturally beyond our power to form the vast image of this mistress called "Sympathetic Nature." (1948, para. 387)

Expanding of Vico's thesis we can find in XX century thought connecting with the tradition of Media Ecology. Two names are important in this context: Walter J. Ong and Eric Havelock. In their works they show how introducing the phonetic alphabet had shaped human sensorium. Ong in his Orality and Literacy is convincing that major effect of introducing the phonetic alphabet was separation sound from sight. Ong writes about writing: "Because it moves speech from the oral aural to a new sensory world, that of vision, it transforms speech and thought as well" (Ong, 2002, p. 83). What is the essence of such transformation? One of the effects of tearing apart sound from sight is loose of harmony. Opposition of art and science can be understood in terms of contrast between oral words and writing, sound and sight. Ong remarks:

By contrast with vision, the dissecting sense, sound is thus a unifying sense. A typical visual ideal is clarity and distinctness, a taking apart (Descartes' campaigning for clarity and distinctness registered an intensification of vision in the human sensorium — Ong 1967b, pp. 63, 221). The auditory ideal, by contrast, is harmony, a putting together. (Ong, 2002, p. 70)

For Ong sound and sight create different modes of reception of the world. Ong remarks:

Sight isolates, sound incorporates. Whereas sight situates the observer outside what he views, at a distance, sound pours into the hearer. Vision dissects, as Merleau-Ponty has observed (1961). Vision comes to a human being from one direction at a time: to look at a room or a landscape, I must move my eyes around from one part to another. When I hear, however, I gather sound simultaneously from every direction at once: I am at the center of my auditory world, which envelopes me, establishing me at a kind of core of sensation and existence. This centering effect of sound is what high-fidelity sound reproduction exploits with intense sophistication. You can immerse yourself in hearing, in sound. There is no way to immerse yourself similarly in sight. (Ong, 2002, p. 70)

If we want to grasp the relation between artistic modes of thinking and scientific we have to be aware of the opposition of eye and ear, sound and sight. Sound, "which envelopes me" and "establishing me at kind of core of sensation and existence" is giving ramification for artistic experience. In this sense we can understand Vico remark that people on the early stages of development of civilization (oral culture) were natural poets.

Expanding of such approach we can find in Eric Havelock's Origins of Western Literacy, where he attributes the ascendency of Greek analytic thought to the Greeks' introduction of vowels into the alphabet, which was invented by Semitic peoples and had consisted only of consonants and some semivowels. In introducing vowels, the Greeks reached a new level of abstract, analytic, visual coding of the elusive world of sound. According to Havelock this achievement presaged and implemented their later abstract intellectual achievements.

Marshall McLuhan expanded these remarks and tries to adapt this mode of thinking to electronic culture, which was shaped by appearance of radio and television. New multisensual forms of representation and sending information are factors of retrieving "poetic wisdom", because they are bringing together mind and senses once again. Electronic culture is not only retrieval of tribal organization, but also electronic culture is retrieval of 
aesthetic organization of knowledge. In Medium Is the Massage McLuhan writes that thanks to acoustic forms of communication we are starting perceiving everything as a work of art:

We have now become aware of the possibility of arranging the entire human environment as a work of art, as a teaching machine designed to maximize perception and to make every day learning a process of discovery. (McLuhan, 2001, p. 68)

According to McLuhan in electronic culture we are recovering the central role of aesthetical experience. Such trends as "design thinking" and "designer of user experience" show that social and cultural praxis certify McLuhan's insight. Technology and art are mixing together creating new entities. The problem is with theoretical frames, which are used to grasp the world around us. Strict divisions are remains of the past. It concerns as well divisions between our mental faculties as divisions between the basic forms of human activity: art, science and technology.

\section{Conclusion}

The phenomena of crisis of humanities are a hallmark of the beginning of twenty first century. One often hears that main reason of that crisis is connected with rapid advance in computers industry and appearance of World Wide Web. The consequences of the technological transformation are connected with deep changes into the shape of knowledge, modes of education and our understanding of the role of art and humanities in the society. Paradoxically the phenomena of crisis of humanities can reveal chance for regain important role of art and humanities in society. We should remember that word "crisis" derives from medicine. In medicine crisis is a critical moment, which demands a solution - positive or negative. The question is: what does the positive solution for art and humanities mean? Return to the past when divisions between basic forms of human activity were rigidly fixed or rethink assumptions concerning relation between senses and mind and find out that art is property of everything? Based on the thought of such authors as G. Vico, M. McLuhan, R. Arnheim and W. J. Ong we proposed to see relation between mind and senses through the perspective of technological determinism and on such basis looking for resolution of crisis of art and humanities.

\section{References}

Arnheim, R. (1969). Visual thinking. Berkley and Los Angeles: University of California Press.

Arnheim, R. (2011). Myślenie wzrokowe (Visual thinking). (M. Chojnicki, Trans.). Gdańsk: Słowo/obraz terytoria.

Drucker, P. (1999). Spoteczeństwo pokapitalistyczne (Post-capitalist society). (G. Karnas, Trans.). Warszawa: Wydawnictwo Naukowe PWN.

Gershenfeld, N. (2005). Fab: The coming revolution on your desktop-From personal computers to personal fabrication. New York: Basic Books.

Malina, R. (2014). Preface. In A. Bureaud (Ed.), Water is in the air: Physics, politics, and poetics of water in the arts. San Fransisco: Leonardo and MIT Press.

McLuhan, M. (1999). Letter to Jacques Maritain from 6 May 1969. In E. McLuhan and J. Szklarek (Eds.), Medium and the light. Toronto, New York: Stoddart Publishing Co. Limited.

McLuhan, M. (2001). Medium is the massage. An inventory of effects. Corte Madera: Gingko Press.

M. McLuhan letter to Frank Kermode. Retrieved $06.10 . \quad 2015$ from http://thisrecording.com/today/2011/10/27/in-which-we-know-nothing-of-his-work.html

Ong, W. J. (2002). Orality and literacy. The technologizing of the word. New York: Routledge.

Pietropaolo, D. (1995). Vichian ascendancy in the thought of Marshall McLuhan. New Vico Studies, XIII.

Vico, G. (1948). New Science. (T. G. Bergin \& M. H. Fish, Trans.). New York: Cornell University Press. 